\title{
Countermeasure Policy on Mining Crime under The Legal Progressive Perceptive
}

\author{
Faisal ${ }^{1}$; Derita Prapti Rahayu ${ }^{2}$; \\ ${ }^{1,2}$ Faculty of Law, Bangka Belitung University \\ Corresponding author's email: progresif_lshp@yahoo.com
}

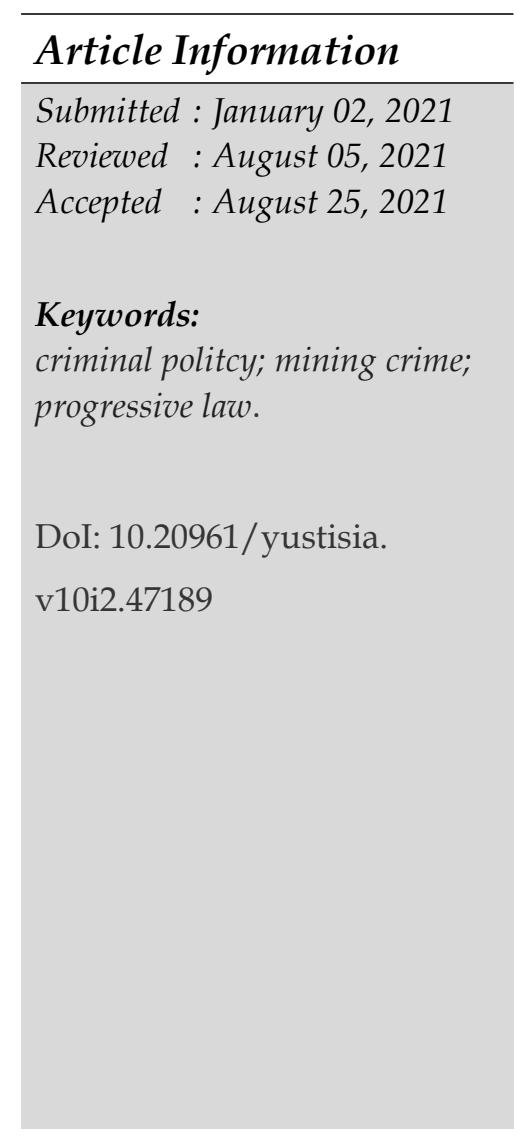

\begin{abstract}
The complexity of mining business governance affects rational actions to tackle mining crime using the criminal policies in a progressive legal dimension. This research focuses on dealing with mining crime using criminal policies and rational efforts in the progressive legal dimension. It was conducted using normative legal research method using secondary data obtained from primary and secondary legal materials. The urgency of this research is to provide guidance towards the application of appropriate rules of mining for the actors in the business. It was also directed to provide references in mining law enforcement through an integral policy. The results showed that criminal policy through penal means in the formulation stage has the ability to regulate licensing crimes, corporate crimes, crimes against reclamation, and criminal obstruction of mining businesses. Moreover, the application stage involves the legal construction of material and formal offenses while the execution stage requires integral law enforcement. It is also important to note that the non-penal means which focuses on prevention maps potential actors with the ability to create the victims while the secondary prevention maps the mining areas with potential conflicts. This means the progressiveness of mining criminal policies rationally in the progressive law dimension enforces certainty and basic ideas underlying the norms.
\end{abstract}

\section{Introduction}

It is important to put forward the opinion of Michel Foucault as quoted by Tania Murray Li that "organization is not to achieve a single dogmatic goal but a specific set of outcomes" as the introductory statement. This means there is a need for continuous efforts to balance all types of relationships between "humans and all their sources of living". There is, however, the possibility of several incompatible "outcomes" which

\footnotetext{
226 Yustisia Volume 10 Number 2 (May-August 2021) Countermeasure Policy on Mining Crime...
} 
produce conflicting or even completely contradictory interventions (Tania Murray Li, 2012: 18).

The legal arrangements in mining such as the licensing law, corporate law, environmental law, administrative law, and criminal law are expected to be managed with due consideration for several aspects of the field such as the carrying capacity of natural resources, environmental sustainability, local wisdom, and social and economic welfare of the community.

The law previously designed to regulate and provide direction for mining governance behavior is in the social field and was formulated based on different variants of the aforementioned aspects. Moreover, the operations of criminal law in society do not only deal with the technique of formulating crime elements against a certain act to determine its qualification for criminal penalty. This is due to the fact that the law is not directly proportional to reality which is characterized by several complexities. Therefore, criminal law academics, law enforcers, and central and local government officials need to pay attention to this complexity, especially with the focus on those associated with contradictions and dilemmas in overcoming mining crimes experiences.

The current political direction of the regulation on mineral and coal licensing authority has experienced a significant change with the all-centralized authority originally held by the regional head reported to have been shifted back to the central government (Derita Prapti Rahayu dan Faisal, 2021: 164). Moreover, previous studies have reported several issues associated with mining, for example, Ahmad Redi showed that the dilemma of law enforcement on PETI (Mining Without Permits) is crucial for the operation of mining business activities. This is due to the consideration of PETI activities as part of the criminal acts regulated in Articles 158 and 160 of the Coal and Mineral Act which also affect destitute people participating in mining businesses to meet daily needs. (Ahmad Redi: 2016: 418).

Danny Z. Herman in "Mining Without Permits (PETI) and the Possibility of Transferring Status to Small Scale Mining" once reported the reasons for the development of PETI as well as several factors which are likely to affect its growth. The article reported one of these factors to be the existence of the mining business for several generations, thereby, leading to the view that mining land is a legacy which does not require a business license. Moreover, the business capital is relatively small and this causes the conduct of mining in a simple or traditional manner without using high-tech equipment (Ade Adhari, 2017: 114).

Derita Prapti Rahayu also reported that the phenomenon of unconventional tin miners (TI) in Bangka Belitung Islands Province indicates the legal norms governing general mining, especially in terms of community mining permits which is known as unconventional mining (TI) cannot work as expected. It is important to note that these unconventional tin miners (TI) do not satisfy licensing requirements before engaging in mining, thereby, causing environmental damage. It was also discovered that the permit issuer, in this case, the Mining Department, only accepts the mining permit application from Business Entities or CVs without focus on individuals. This is associated with the 
difficulties experienced by low-income individuals mining to meet daily basic needs without the resources to form a business entity (Derita Prapti Rahayu, 2012: 501).

This shows most miners conduct mining activities without permits and this means these unconventional miners have committed a mining crime or violated the provisions of regional regulations in the least. This complexity and dilemma in mining governance require the attention of criminal law researchers and law enforcers to recall the fundamental principles of criminal law. In this context, there is a need to remember and carefully understand the teachings of criminal law scientist, Sudarto, that law is a normative social science (normative maatschappij wetenschap) about human relations. This indicates studying law (law science) is inseparable from understanding human behavior in society (behavioral sciences) and social sciences. Therefore, a law degree needs to integrate a juridical and social science approach (Sudarto, 2009: 02).

Sudarto has provided an initial description of the important elements in defining criminal law and this was further emphasized by Barda Nawawi Arief that it is a normative social science. There is, therefore, a balance between the normative and social aspects of understanding criminal law. It is also important to note that there are three pillars of criminal law known as a criminal triad and these include criminal acts, criminal liability, and sentencing. Meanwhile, these terms are unlawful, wrong, and criminal according to Sauer, Packer was reported to have defined the three concepts as an offense, guilt, and punishment while Saner referred to them as onrecht, schuld, and strafe (Faisal, 2021:09).

It is appropriate to closely intersect the normative application of the criminal provisions in the Coal and Mineral Act with the dynamics of the community in relation to the complexity and dilemma of mining criminal law enforcement. Meanwhile, it is impossible to evaluate the social behavior of a community based on only the normative standards due to the fact that the mining governance behavior is also greatly influenced by economic, social, cultural, and local wisdom factors. This means it is going to be a problem to engage only in partial implementation of mining criminal law enforcement and not through integral means based on criminal policies.

Mining has the ability to generate instant money and sometimes in significant quantities and this means it creates hope for those willing to change their fate quickly. Moreover, it does not require high knowledge and expertise but is only based on experience, energy, and courage. This, therefore, makes mining a very attractive option for livelihood especially for those with limited education and strong physical ability. It also provides an opportunity for them to enjoy their lives by meeting their daily economic needs (Iskandar Zulkarnain, 2010: 34).

Uncontrolled mining activities, however, have negative social impacts on the community as observed in the widening social inequalities and the emergence of a culture of consumerism in society. This emergence of a new social class is prone to social jealousy which further triggers conflict either due to the seizure of mining areas or conflicts of interest (Ikhsan Fuady, 2014: 10).

The local wisdom existing in the Bangka Belitung Islands is generally related to the mining activities of the people and this was observed from the studies conducted in 2016 to be based on the tin ampak. This is a condition where tin has no economic value

228 Yustlsla Volume 10 Number 2 (May-August 2021) Countermeasure Pollcy on MInlng CrIme... 
due to its hollowness or is only made from ordinary sand. Tin seems to be the wisdom of the previous community directed towards sustaining the environment for future generations. Moreover, the value of the tin ampak local wisdom in history is an effort to divide the areas to be mined and those not to be mined for the purpose of community welfare and environmental sustainability (Derita Prapti Rahayu, 2021: 63).

The integral policy is understood to have a holistic paradigm that simultaneously investigates and transcends legal positivism which is focused on the application of the law based only on norms without the aspects of behavior, values, and social dynamics of the community. The failure of this legal positivism in guiding human life is associated with its mode of thinking which consistently maintains the influence of reductionism, determinism, and objectivism in the science of law. Meanwhile, progressive law offers something more than legal positivism which is understanding law with a holistic paradigm (Faisal, 2010; 64).

It is, however, important to note that progressive legal discourse is not devoid of conversation among campus academics as indicated by the summary of Faisal's thoughts presented by Hyronimus Rhiti's "The Meaning of Progressive Law" delivered at a meeting to confirm the clear and firm scientific status of progressive law.

The first is the ontological basis of progressive law which is humans and reality. The second is the epistemological basis of progressive law which is non-deterministic induction and this means the law comes from reality or empirical studies without being deterministic or certain but more related to humans and their behavior as well as the non-logical deduction which means more social than regulatory logic. The third is the axiological basis of progressive law which means the transcendental or divine values guiding good behavior as well as the values of justice, populism, humanity, and progressiveness. Moreover, progressive law science also has a system consisting of a single unit which does not cancel each other out and this involves human foundation, conscience, behavior, juridical text, reality, and liberation (Faisal, 2015: 18).

The consideration of the notion of progressive law shows that overcoming and enforcing mining law does not merely focus on the actualization of the total enforcement approach but also on the arguments and analysis of actual enforcement as an integral or holistic important aspect.

The philosophical foundation of progressive law is most commonly known as a legal adage for humans and not the other way around. The law exists for humans when the legal subject is free from mechanistic and final determinative ways of thinking and this means it is impossible to observe the reality of the complex and fluid mining laws only from a linear and conventional perspective. The progressive law proposed by Satjipto Rahardjo takes a clear distance and goes beyond legal positivism.

Overcoming mining crimes is not as easy as overcoming other crimes such as persecution, theft, fraud, and some common ones. This means solving mining governance issues with a criminal dimension needs a policy approach. It is, however, important to note that criminal policy standardization is an inseparable part of a social policy designed based on the belief that society is the subject of social protection policy towards creating welfare for the community. This means it is also important to resolve mining crimes through a rational criminal policy approach and this involves the application of rational methods. 
According to Hoefnagels, a rational criminal policy is differently explained as the rational root of the total response to crime. This is considered important due to the fact that the conceptions of crime and power or the process of criminalizing are often emotionally defined (Faisal, 2020: 69). Moreover, the criminal policy designed to tackle mining crimes rationally does not rule out the possibility of overcoming the problem using non-criminal instruments or means. This, therefore, means the criminal policy is focused on deciding between penal and non-penal means of punishment based on the provision of normative and social science.

The penal means allow law enforcers to involve repressive actions based on the foundation of normative science of criminal law while the non-penal suggestion calls for a criminal law enforcement situation fostered and developed in a preventive atmosphere to understand the root causes of the crime better and the provision of remedial actions. The non-penal means is believed to be a good coping method in line with the understanding of social science.

The application of criminal policies through a progressive legal dimension in tackling mining crimes is important considering the tendency of normative criminal law science which does not provide space for the discourse of social science and more importantly the philosophical issue of mining governance which is ecological justice. The integrated criminal policy is, however, expected to review mining crimes based on penal means which are criminal instruments or normative criminal law as well as non-penal means which are instruments other than criminal or social science.

The problems formulated to be solved by this research include (1) How can mining crimes be tackled through criminal policies? (2) What is the rational effort of mining criminal policies in the progressive legal dimension? The purpose of this research is oriented towards the theoretical aspect with the focus on providing conceptual answers on the approach to be used in tackling mining crimes through a criminal policy framework in the progressive legal dimension. The findings are, therefore, expected to be useful from a functional or practical perspective through their concrete operationalization or enforcement in reducing mining crimes.

\section{Research Methods}

This is normative legal research and the data were obtained only from secondary sources including primary, secondary, and tertiary legal materials. The primary legal materials are Law Number 3 of 2020 concerning Amendments to Law Number 4 of 2009 concerning Mineral and Coal Mining while the secondary legal materials are literature studies and documents covering all research related to the legal issues under study in the form of doctrine and results presented in books and electronic scientific journals.

\section{Research Results and Discussion}

\section{A. Mining Crime Management through Criminal Policy}

The process of handling mining crime through the rational efforts of the criminal policies associated with mining activities is inseparable from environmental problems irrespective of the form used due to the fact that mining in essence means changing the natural order. This means mining

$230 \quad$ Yustlsla Volume 10 Number 2 (May-August 2021) Countermeasure Pollcy on MInIng Crlme... 
activities conducted at any place or time usually lead to the direct destruction of the environment.

There is, however, the need to consider mining exploitation in the discussion related to the creation of a sustainable society. Capra defines this concept as ecoliteracy which is a condition where people understand ecological principles and live according to them. This basically means humans are required to take advantage of the natural environment such as local wisdom related to environmental management in accordance with relevant policies.

Mining is one of the sectors used in supporting the country's economy and is observed to have become the prima donna of almost all regions, especially those using mining products as natural wealth. This is observed from the quite high Regional Original Opinion (PAD) for the mining sector in several regions. Meanwhile, it is undeniable that mining business activities cause environmental changes and this means these activities harm the environment despite their economic benefits (Dwi Haryadi, 2018: 2083-2084).

Mining crimes such as mining without permits, manipulation during the exploration and exploitation stages, and others are rife and considered an open secret. Moreover, mining without a permit usually leads to non-compliance with good mining practices, thereby, causing excesses such as environmental pollution (Ade Adhari, 2013: 03).

The Coal and Mineral Act generally recognizes several mining business licensing schemes with a minimum of nine forms of permits discovered to be recognized by Article 35 and these include IUP, IUPK, IUPK as a Continuation of Contract/Agreement Operations, IPR, SIPB, assignment permits, Transport and Sales Permits, IUJP, and mining license (IUP) for Sales. The inability to fulfill this licensing administration or conduct it according to the applicable provisions leads to its inclusion in the criminal qualification related to licensing. Moreover, the criminal provisions formulated in the Minerba Act are quite severe despite their administrative nature as indicated by the threat of 5 years in prison and a fine of 100 billion rupiahs for conducting mining activities without obtaining a permit as observed in Article 35.

The basic understanding of the Coal and Mineral Act as part of administrative criminal law makes it natural to put forward Barda Nawawi Arief's perspective that this type of law is essentially a manifestation of criminal law policy to enforce or implement administrative law. This means it is a form of "functionalization of the operationalization or instrumentalization of criminal law in the field of administrative law". It is, therefore, an embodiment of criminal law politics tool to enforce administrative law norms (Untung Setiyahadi and Sukarmi, 2017: 322).

The law enforcement officials in the mining sector also often find it difficult to separate the concepts of administrative, civil, and criminal laws in mining cases. This means the Coal and Mineral Act and the Environmental Protection 
and Management (PPLH) Act need to be observed by all mining business actors (Maizardi and Ebit Bimas Saputra, 2018: 71). Moreover, the 2009 PPLH Act used to replace the 1997 PPLH Act was discovered to be functioning as the main law which brings fundamental changes in environmental management arrangements in Indonesia.

First, the criminal act was formulated to ensure exceeding ambient air quality, water quality, seawater quality, and environmental damage standards. Second is to provide minimum and maximum penalties and the third is to regulate convictions for violations of quality standards, expand evidence, integrate criminal law enforcement, and regulate corporate crime (So Woong Kim, 2013: 417). The spread of crime in the mining sector has become a separate challenge for criminal law enforcement using the substantive norms in the Coal Mineral Law and the PPLH Law.

The interpretation in this study shows these laws to be part of the overall norms of formal criminal law. This means they have the ability to qualify the acts considered to be mining crimes and regulate them in line with material criminal law norms. Meanwhile, the criminalization efforts include penalties that do not stop with the stipulation of an act as being prohibited. This is necessary considering the possible consequences of this act which the criminal law needs to emphasize in line with the capacity and work power of law enforcement agencies to avoid overstatement or overbelasting_(Muhammad Ali Zaidan, 2016: 241). It has also been reported by Sudarto that criminal law has limited ability to tackle crime but only serves as a remedy for curricularity symptoms and not a solution to eliminate the causes.

These limitations were also discovered to be caused by the nature and function of the criminal law itself and this further shows that criminal (legal) sanctions are not a remedy (remedium) to overcome the causes (sources) of disease but simply to resolve the symptoms or consequences to allow other efforts to tackle the crimes (Ateng Sudibyo, 2019: 32).

Marc Ancel defined criminal policy as "the rational organization of crime control by society". This means the criminal policy is a rational arrangement or arrangement of efforts to control crime with the ultimate goal of "protecting society" (Ratri Novita Erdianti, 2018: 270). It is also a rational attempt by society to prevent and react to crime and this is considered a logical consequence. The use of criminal law as a policy is actually not a necessity. It is also important to note that there is no absoluteness in policymaking due to the issue of assessment and selection of different alternatives being faced by the people.

Criminal policies or crime prevention are essentially an integral part of the efforts to protect society (social defense) and also to achieve social welfare. This shows the ultimate or main goal of criminal policy is the protection of society and achievement of social welfare, thereby, making it an important aspect of public policy (Iza Fadri, 2010: 445). 
There is, however, the need for the criminal policy to integrate the penal and non-penal facilities in performing its function of protecting society in order to achieve social welfare for the community within the framework of national development (Rizka Fakhry Alfiananda, 2018: 89). The integration scheme proposed by Hoefnagels indicates the possibility of combating crimes using three methods (Faisal, 2020: 75) which include (a) penal means which involves the application of criminal law, (b) non-penal means which involves prevention without punishment through the handling of criminogenic factors, and c) influencing the view of society or public on crime and punishment using mass media facilities. It is also possible to refer to this third method as a non-penal means.

Criminal policy efforts are part of social policy to tackle mining crimes and are also included in the penal and non-penal means of the social protection scheme. It is important to note that penal means are usually pursued through the formulation stage which involves matters relating to the substantive norms of criminal law, the application stage which focused on matters relating to the functionalization or operationalization of applying the criminal law norms, and the execution stage which involves matters pertaining to the running of the two previous stages.

The determination of solutions to mining crimes in the criminal policy scheme through penal means focuses on the formulation stage which deals with the substantive norms of mining criminal law as indicated in the Coal and Mineral Act. Article 1 paragraph (1) shows the criminal dimensions and this means an act is committed with disgrace and can be criminally reproached. Moreover, Law No. 3 of 2020 as amended from Law No. 4 of 2009 concerning the Coal and Mineral Mining in Coal and Mineral Act shows the qualifications for mining offenses are regulated in Articles 158, 159, 160, 161, 161 A, 161 B paragraph (1), 162, 163, and 164 .

The qualifying acts related to mining crimes in the Coal and Mineral Act include Licensing (Article 158), Submitting Wrong Reports and False Information (Article 159), Utilization of Permits not in Accordance with its Purpose (Article 160), Smuggling, Transportation, and Sales Minerba as well as Mineral and Coal Processing without Rights (Article 161), Transfer of Mining Business Permits or Narrow Meaning of Embezzlement of Mining Business Permits (Article 161A), Not Carrying Out Post-Mining Reclamation and Not Providing Post-Mining Reclamation Guarantee Funds (Article 161 B paragraph 1), Obstructing Mining Business Activities (Article 162), Mining Corporation Crimes (Article 163), and the additional criminal offenses related to Articles 158, 159, 160, 161, 161a, 161b, 162, and 164.

The criminal policy of tackling mining crimes through penal means depends on the application stage which involves the use of substantive legal norms. These penalties need to be applied with the consideration for the legal 
construction built from the mining criminal formulation in the Coal and Mineral Act. It is, however, possible to divide the offenses in criminal law into formal and material. Moreover, a generic crime is an offense or an act prohibited by law and deemed perfect or fulfilled with consequences while a specific crime is an offense deemed perfect or fulfilled as soon as the act is committed without requiring consequences (Derita Prapti Rahayu, 2015: 228).

The application stage shows the mining crime is operationalized by considering its formulation as a material or a formal offense. The construction of a material offense depicts a mining criminal act which causes environmental pollution and this means it does not have to be due to the evidentiary aspect of licensing administration. Meanwhile, in formal offense, the coverage of an action by the element of offense means it is perfect without having to wait for the consequences. It is, however, important to note that the actions related to the criminal aspects of licensing are closely associated with formal offenses.

The execution stage is concretely related to the previous stages of formulation and application. It is determined by the legal apparatus used by the regional government officials in conducting mining criminal law politics as well as the facilities and infrastructures. Moreover, the rational efforts of criminal policy cannot simply be focused only on the penal means due to the need for its integral implementation. This means the evaluation of the crimes in the mining world requires an in-depth analysis of the complexities influencing their emergence. This, therefore, makes the application of non-penal means urgent as a response to the rational action within the framework of criminal policy.

The dilemmas in mining governance have been discussed at the beginning of this research and those associated with funding complexity were found to be usually driven by several dominant factors such as the economic and welfare, awareness and knowledge of the community regarding the application for mining business permits, local wisdom, and licensing management considered to be very procedural and bureaucratized.

Some of these factors have triggered the prevention of mining crimes through rational actions other than the use of penal means by law enforcement agencies. This shows the non-penal means are needed as a preventive measure and also to determine the root problems and solutions to very complex mining crimes. This prevention effort is, however, divided into two general models including the primary and secondary.

The focus of the primary prevention is to carefully observe the potential perpetrators of mining crimes which mostly include the elite and small community actors. These elites tend to fall within the area of the licensing regime but there is a possibility of variation in the modes starting from the provision of easy licensing as well as weakening and omitting the aspect of supervision. Moreover, the tendency of these elite actors to commit crimes is due to weak public control and a lack of transparency in the management of permits. Therefore, it is important to manage public information, control internal supervision, and 
the public in mining business licensing services to reduce the activities of these elites. It is also very important to map the licensing flow and management to unravel the tangled threads of manipulation and potential licensing rents.

Small community actors can also be rehabilitated by providing continuous guidance and supervision to ensure they understand mining business governance which adheres to and maintains the principles of environmental sustainability. Moreover, the central and regional governments also need to be more active in developing the economic sector outside mining businesses to ensure lowincome people do not only depend on the mining sector for their daily needs.

The secondary prevention in non-penal means is expected to be largely determined by mapping the mining areas. This is necessary due to the fact that the social field of society shows the mining sector has the ability to attract other potential sectors such as fishing occupied by fishermen, plantations run by farmers, and the development of the tourism sector. The mapping process is planned to be a long-term solution to minimize the clashes between these aforementioned development sectors.

\section{B. Rational Efforts to Mining Crime Policy in Progressive Legal Dimension}

It is important to examine the changes in the Minerba Act of 2020 due to the several significant shifts in the formulation of norms in different aspects of the mining sector such as the matters relating to licensing arrangements, reclamation, and provisions of criminal sanctions. The amendment to the act was, however, found to be far from a rational effort.

Progressive law displays its scientific status rationally as an idea and concept. This means the legal basis to be built is balanced and serves as a holistic way of thinking. This is associated with the fact that law is a dynamic apparatus used in teaching humanity and justice and also serves as the link between the aspects of regulation and behavior.

The framework developed in the new Minerba Act is in a quite satisfying context with the mining licensing authority observed to have been transformed into a centralized norm in the power of the central government. This means the politics of licensing law is retreating to the New Order era where everything was completely centralized while the reform era gave full authority to local governments within certain limits through the principle of decentralization. It is currently repossessed by the central government with the abolition of Articles 7 and 8 in the Minerba Act of 2020 and reaffirmed in Article 6 of the authority of regional heads to grant mining permits.

The legal politics applied in the Minerba Act of 2020 only focuses on the assistance with the government observed to have forgotten the reality of the social behavior of the mining community in different regions. This research imagined the possibility of the relevant ministries of the central government conducting supervision and prosecution in more than five hundred districts and cities. Diverse styles and cultures which determine the legal cultures of different 
mining communities were also considered. Therefore, progressive law believes this centralized aspect of licensing is not responsive and tends to be autonomous in the name of power.

The regulations in the Minerba Act of 2020 do not carefully examine the aspects of humanity and justice. It is, therefore, possible to intersect these aspects based on the considerations of their benefits in terms of efficiency and effectiveness. The changes in regulations in the Minerba Law focus on these deficits but the formulation of Article 162 in the progressive legal dimension is very far from humanity and justice. It is important to note that the purpose of punishment has not left the classical era as indicated by the retaliation in the desire to advance the human side of the perpetrators, victims, and society. The progressive legal perspective, however, finds it difficult to agree that the current purpose of punishment is merely to provide retaliation through imprisonment and other instruments. This is due to the fact that objectivity is very important in contextual punishment.

The policy of criminalizing and decriminalizing an act depends on the goals to be achieved. This is observed when a person or group of people protests against the rejection of mining activities harming them and their environment. The formulation of criminal sanctions in Article 162 was, therefore, found not to be appropriate.

The value of human progressivity and justice has been reduced to a mere political choice with the criminal policies implemented in the formulation stage discovered to be irrational. Meanwhile, progressive law offers criminal policies founded on the basic idea of a balance through an integrated approach with the purpose of punishment not only based on retaliation but rather to build social harmony and dynamism. This means not all actions of society necessarily need punishment. Therefore, the criminal law needs to be able to restrain itself to provide flexibility for non-criminal instruments to ensure a significant reduction in criminal activities associated with mining.

The progressiveness of formulating mining criminal policies without scientific and policy considerations makes the orientation of a norm lose the essence of punishment in accordance with the principles of values, benefit, and humanity. Moreover, the criminal provisions were found to be firm and detailed in the aspects guaranteeing the security of the mining business owners while other aspects especially those related to post-mining reclamation obligation are unclear.

Article 161B of the Minerba Act of 2020 provides additional provisions for criminal sanctions in the form of imprisonment as well as for IUP and IUPK holders that refuse to implement the provisions designed for reclamation in addition to the administrative sanctions and fines in Article 151.

The problem is that the administrative sanctions seem to be the first instrument rather than the provisions of imprisonment for permit holders that refused to implement post-mining reclamation and do not place reclamation guarantee funds. This shows the government is more careful about imposing 
criminal charges on mining permit holders than giving penalties to those trying to obstruct mining businesses. Therefore, this raises suspicion on the disposition of the state to environmental preservation and sustainability.

The amendments to the Minerba Act of 2020 in the progressive legal dimension to regulate mining permits, post-mining reclamation, and criminal provisions were also observed not to have been implemented rationally based on scientific studies and policy perspectives. The rational effort is expected to be through an integral mining criminal policy designed based on several considerations. First, reformulation of a norm is required to guarantee the principle of certainty and the basic idea underlying the creation of the rule, second, consideration of the regulation's benefits in terms of effectiveness and efficiency, third, the regulations need to guarantee the actualization of the expected system, and, fourth, each regulation is required to be responsive and fair.

\section{Conclusion}

The complexity of mining business governance which causes mining crimes needs to be addressed by rational efforts using criminal policies. This involves using integral methods of criminal policy which involves the combination of both penal and nonpenal means. The penal aspect is expected to determine the process of the formulation, application, and execution stages of the criminal act while the non-penal aspects are designed to work as a crime prevention strategy by implementing two prevention models which are the primary and secondary models.

The rational effort of the mining criminal policy in the progressive legal dimension depends on the philosophical foundation that laws are for humans and not humans for laws. This means all the stages need to be conducted from a holistic perspective with the balance between the aspects of regulation and behavior as well as the interests of humanity and justice required to be an important part of formulating the rational efforts. This is necessary to ensure the achievement of policy progression to ensure the principle of certainty and accommodate the basic idea used in forming the norms. Moreover, the principle of benefit in terms of effectiveness and efficiency is also required to guarantee a law-based system. Another important thing is that every regulation is required to have a value of responsiveness and justice.

\section{Acknowledgments}

The authors appreciate the Institute for Faculty of Law and Research and Community Service, the University of Bangka Belitung for funding this research.

\section{BIBLIOGRAPHY:}

Ade Adhari, dkk, (2013). Kebijakan Hukum Pidana terhadap Tindak Pidana di Bidang Pertambangan Mineral dan Batu Bara dalam Undang-Undang Nomor 4 Tahun 2009 tentang Pertambangan Mineral dan Batu Bara, Jurnal Diponegoro Law Review, 1(02), 03. 
(2017). Kebijakan Kriminal dalam Mencegah dan Menanggulangi Tindak

Pidana Penambangan Tanpa Izin di Indonesia, Jurnal Bina Hukum Lingkungan, 2(01), 114.

Ahmad Redi, (2016). Dilema Penegakan Hukum Penambangan Mineral dan Batu Bara Tanpa Izin pada Pertambangan Skala Kecil (Dilemma of Law Enforcement in Small Scale Illegal Mining), Jurnal Rechtsvinding, 5(03), 418.

Ateng Sudibyo, (2019). Kebijakan Kriminal Terhadap, Gay, Biseksual dan Transgender

(LGBT) Dikaitkan Dengan Delik Kesusilaan di Dalam Kitab Undang-Undang Hukum Pidana, De Lega Lata Jurnal Ilmu Hukum UMSU, 4(01), 32.

Derita Prapti Rahayu dkk, (2021). Dimensi Kearifan Lokal terkait Pertambangan Rakyat, Yogyakarta, Istana Agency, 2021.

(2021). Politik Hukum Kewenangan Perizinan Pertambangan PascaPerubahan Undang-Undang Minerba, Jurnal Pandecta, 16 (01), 164 , (2020). Metode Penelitian Hukum, Yogyakarta: Thafa Media.

(2012). Budaya Hukum Penambang Timah Inkonvensional (TI) terhadap Mekanisme Perizinan Berdasar Peraturan Daerah Pengelolaan Pertambangan Umum di Propinsi Kepulauan Bangka Belitung, Jurnal Masalah-Masalah Hukum, 41(04), 501.

(2015). Delik Izin Lingkungan yang Terabaikan Kajian Putusan Mahkamah Agung Nomor 258 K/Pid.Sus/2012, Jurnal Yudisial, 8(02), 228.

(2016). Kearifan Lokal Tambang Rakyat sebagai Wujud Ecoliteracy di Kabupaten Bangka, Jurnal Ius Quia Iustum, 2(23), 322.

Dwi Haryadi, (2018), Implementasi tanggung Jawab Reklamasi Pertambangan Timah di Pulau Belitung, Jurnal Hukum Progresif, 12(02), 2083-2084.

Faisal dan Rustamaji, (2021). Pembaharuan Tiga Pilar Hukum Pidana dalam RUU KUHP, Jurnal Magister Hukum Udayana, 10 (2), 299

, (2020). Politik Hukum Pidana, Yogyakarta: Thafa Media.

(2015). Pemaknaan Hukum Progresif Upaya Mendalami Pemikiran Satjipto Rahardjo, Yogyakarta, Thafa Media. , (2010). Menerobos Positivisme Hukum, Yogyakarta, Rangkang Education.

Iskandar Zulkarnain, (2010). Strategi pengembangan wilayah pertambangan rakyat di Kabupaten Bombana. Jakarta, LIPI Press.

Iza Fadri, (2010). Kebijakan Kriminal Penanggulangan Tindak Pidana Ekonomi di Indonesia, Jurnal Hukum, 3(17), 445.

Ikhsan Fuady, Dampak Penambangan Timah Terhadap Keadilan Sosial dan Kerusakan Lingkungan, http://skpm.ipb.ac.id/wp-content/uploads/2014/01/1.-MakalahSeminar-TSH-2014_Ikhsan-Retno-.pdf, 2014

238 Yustlsla Volume 10 Number 2 (May-August 2021) Countermeasure Pollcy on MInlng CrIme... 
Maizardi dan Ebit Bimas Saputra, (2018), Penegakan Hukum Terhadap Tindak Pidana Pertambangan Batuan Non-Logam pada Tanah Hak Milik Masyarakat (Studi Pada Satreskrim Polres Kerinci), Jurnal Unes Law Review, 1(01), 71.

Muhammad Ali Zaidan, (2016). Kebijakan Kriminal Kejahatan terhadap Ideologi Negara di Tengah Pusaran Globalisasi, Jurnal Pandecta, 11(02), 241.

Ratri Novita Erdianti, (2018). Alternatif Pemidanaan terhadap Pelaku Penyalahgunaan Narkotika dalam Kebijakan Kriminal di Indonesia, Jurnal Legality, 25(02), 270.

Rizka Fakhry Alfiananda, (2018). Masyarakat Hukum Adat dalam Skema Kebijakan Kriminal di Bidang Perusakan Hutan, Jurnal Wacana Hukum, 24(02), 89.

Sudarto, (2009). Hukum Pidana 1 Edisi Revisi, Semarang: Yayasan Sudarto Fakultas Hukum Universitas Diponegoro.

So Woong Kim, (2013). Kebijakan Hukum Pidana dalam Upaya Penegakan Hukum Lingkungan Hidup, Jurnal Dinamika Hukum, 13(03), 417.

Tania Murray Li, (2012). The Will to Improve "Perencanaan, Kekuasaan, dan Pembangunan di Indonesia, Jakarta: Marjin Kiri.

Untung Setiyahadi dan Sukarmi, (2017). Kebijakan Hukum Pidana terhadap Tindak Pidana Pertambangan Mineral dan Batubara (Study Kasus Normalisasi Kali Bebeng Kabupaten Magelang), Jurnal Hukum Khaira Ummah, 12(02), 322. 